\title{
PETER THE GREAT AS ANTICHRIST: THE SECULAR SOURCES OF AN OLD BELIEVER COMPILATION FROM HOLY SCRIPTURE*
}

\author{
Maureen Perrie \\ University of Birmingham, \\ Birmingham, UK
}

This article is devoted to an Old Believer work about Peter the Great, known as A Compilation from Holy Scripture about the Antichrist, which was first published in 1861. Some scholars have suggested that the work dates back to Peter's reign, when many traditionally minded Orthodox Christians regarded the tsar as the Antichrist. The author of this article argues, however, that the work dates from the early nineteenth century, and that the case it makes for Peter's identity as Antichrist is based primarily on tales about the tsar which were published in the late eighteenth century. On the basis of anecdotes about Peter's conception, for example, the author of the Compilation drew a comparison with the Annunciation, the Epiphany, and the Feast of the Circumcision, to demonstrate a sacrilegious parallel between Peter's biography and that of Christ, which "proved" that Peter was the Antichrist. The Compilation also cites works which seem to blasphemously suggest that Peter was God incarnate, in order to argue that the tsar was the embodiment not of God, but of Satan. Finally, when one work praised Catherine the Great for representing "the spirit of Peter the Great", the compiler concluded that the spirit of all subsequent Russian rulers was also the spirit of Peter, that is, the spirit of the Antichrist. This is an idiosyncratic version of the argument made in the late eighteenth century by Evfimii, the founder of the Old Believer sect of the beguny, that Peter had founded a dynasty of Antichrists, and that all "true Christians" should flee from his realm. The distinguished Russian scholars Viktor Zhivov and Boris Uspenskii have argued that the metaphorical sacralisation of the monarch, in secular eighteenth-century panegyrics, was interpreted literally by some Old Believers and contributed to their identification of Peter as the Antichrist. The author of this article suggests that a similar role was played by more popular works such as the collections of anecdotes which presented the tsar as a God-like figure.

Keywords: Peter the Great, Antichrist, Old Believers, Evfimii, beguny, V. I. Kel'siev, sacralisation of the monarch

* Citation: Perrie, M. (2021). Peter the Great as Antichrist: The Secular Sources of an Old Believer Compilation from Holy Scripture. In Quaestio Rossica. Vol. 9, № 1. P. 281-294. DOI 10.15826/qr.2021.1.579.

Цитирование: Perrie M. Peter the Great as Antichrist: The Secular Sources of an Old Believer Compilation from Holy Scripture // Quaestio Rossica. Vol. 9. 2021. № 1. P. 281-294. DOI 10.15826/qr.2021.1.579.

(C) Perrie M., 2021

Quaestio Rossica • Vol. 9 • 2021 • № 1, p. 281-294 
Статья посвящена староверческому сочинению о Петре Великом, известному под названием «Собрание от Святого Писания о Антихристе», впервые опубликованному в 1861 г. Ряд ученых предполагали, что это сочинение относится к царствованию Петра, когда многие традиционные православные христиане смотрели на царя как на Антихриста. Автор статьи, однако, считает, что это сочинение относится скорее к началу XIX в. и что доводы составителя «Собрания» о тождестве Петра с Антихристом основаны главным образом на сказаниях о царе, опубликованных к концу XVIII в. На основе анекдотов о зачатии Петра, например, составитель проводил сравнение с Благовещением, Богоявлением и Обрезанием Господним, проводя кощунственную параллель между биографией Петра и жизнью Христа, для того чтобы «доказать» тождество Петра с Антихристом. Составитель также цитирует сочинения, якобы свидетельствующие о том, что Петр является воплощением Бога; по его мнению, такие богохульные сочинения скорее доказывают обратное что царь воплощает не Бога, а Сатану. Наконец, когда один автор называет Екатерину II воплощением духа Петра Великого, составитель делает вывод, что дух всех преемников Петра - это также дух Петра, то есть дух Антихриста. Это является своеобразным вариантом учения Евфимия, основателя староверческой секты бегунов, который к концу XVIII в. отстаивал точку зрения, что Петр основал династию Антихристов и что все истинные христиане должны убегать из проклятого царства его. Известные российские ученые В. Живов и Б. Успенский предполагали, что метафорическая сакрализация монарха в светских панегирических сочинениях XVIII в., интерпретированная буквально некоторыми староверами, содействовала их отождествлению Петра с Антихристом. Автор данной статьи заключает, что подобную роль играли более популярные сочинения конца XVIII в. вроде собраний анекдотов, изображающих царя как богоподобную личность.

Ключевые слова: Петр Великий, Антихрист, староверы, Евфимий, бегуны, В. И. Кельсиев, сакрализация монарха

In their influential essay, Tsar and God, first published in 1987, Viktor Zhivov and Boris Uspenskii argued that the metaphorical sacralisation of the monarch in eighteenth-century Russian baroque works - where the tsar was compared to God or Christ - was interpreted literally by bearers of traditional Russian culture such as the Old Believers, and seen by them as a direct identification of the tsar with God [Живов, Успенский, с. 131]. In particular, they note that the description of Peter the Great as "thy God, O Russia”, in Lomonosov's famous Ode on the nameday of Peter Fedorovich in 1743, was regarded by Old Believers as blasphemous and as an indication that Peter was the Antichrist. As evidence of this, the authors cite a quotation from the Ode in the work known as A Compilation from Holy Scripture about the Antichrist, first published in London by V. I. Kel'siev in 1861 [Там же, с. 178]. 
Zhivov and Uspenskii do not offer a dating for this work, describing it only as an Old Believer tract or composition [Живов, Успенский, с. 131, 139], but their awareness that it includes a quotation from Lomonosov's Ode of 1743 suggests that they assume it was composed after that date. Some scholars, however, have viewed it as a work written in the reign of Peter the Great himself, while others date it as late as the first quarter of the nineteenth century. In this article I propose to examine the dating of the work by considering the ways in which its anonymous author makes use of a number of secular sources published in the late eighteenth century in order to develop his case for the identification of Peter as the Antichrist.

\section{Peter the Great as Antichrist: before and after 1725}

The notion that Peter the Great was the Antichrist was widely held not just by Old Believers but also by many traditionally minded Orthodox Russians throughout much of the tsar's reign. This notion arose against the background of eschatological ideas that had expected the world to end in 1666 , and suspicions that the authors of the Church reforms which were approved in that year - Patriarch Nikon and Tsar Aleksei Mikhailovich - were either the Antichrist or his precursors. When the Apocalypse did not occur in 1666, it was recalculated to 1691 , and thereafter to various later dates which were consistent with the idea that Peter (whose sole rule began in 1696) was the Antichrist. Peter's Westernising reforms provided further evidence of this: the tsar's espousal of beard-shaving and imposition of "German" dress codes, for example, were seen as a new triumph for the Latinism of the Roman Catholic Church over Eastern Orthodoxy, and hence as a sign of the third and final apostasy from the true faith that would herald the end of the world [Перри].

Peter's death in 1725, unaccompanied by the Apocalypse, might have been expected to put an end to ideas of the Antichrist on the Russian throne. And, indeed, although memories of Peter as Antichrist persisted in some circles, apocalyptic thought became more muted for the next halfcentury, and the Antichrist was seen more as a spiritual than as a physical entity [Шмурло, с. 18-19]. Yet, at the end of the century, the idea of Peter as Antichrist underwent a remarkable revival in the teaching of Evfimii, a former military deserter who had previously been a member of the Old Believer sect of the Filippovtsy.

In 1782-1783, the government of Catherine II made an important concession to the Old Believers, abolishing the double tax which had been imposed on them in 1716 by Peter the Great, and removing the requirement for them to register as schismatics (raskolniki) in the census. Many members of even the most radical sects, including the Filippovtsy, welcomed this concession: Evfimii, however, regarded any involvement with the tsarist state as subservience to the Antichrist, and he criticised the readiness of his former associates to register for the general population census [Мальцев, гл. IV]. The census implemented by Peter in 1718 (the "first revision") had, he argued, imposed strict social and political controls over the people, 
restricting their former freedoms [Евфимий, 1862a, с. 248]. Because of all such evils that Peter had introduced into Russia, Evfimii advised his followers to flee from the power of the tsarist state [Евфимий, 18626, с. 269-270].

Apart from his condemnation of the census, Evfimii's greatest innovation to Old Believer apocalyptic teaching was his claim that Peter was not only the Antichrist incarnate himself, but that he had created a dynasty of Antichrists, by issuing the decree of 5 February 1722 on the succession to the throne, which enabled him to appoint his own heir [Евфимий, 1862a, c. 262]. With this claim, Evfimii established the concept that some Russian historians have described as that of the "dismembered" (raschlenennyi) Antichrist; that is, of the Antichrist embodied in the series of Russian rulers beginning with Peter the Great [е. g. Гурьянова, с. 38-52]. This idea was retained after Evfimii's death in 1792 by his followers, who came to be known as the beguny ("Runaways") or stranniki ("Wanderers"), and who invoked Peter's image as Antichrist in order to justify their refusal to interact with the demands of the current ruler, such as registration for the latest census and the payment of taxes.

Russian officialdom knew very little about the beguny before the 1850s, when the government dispatched a series of investigative expeditions to the provinces where Old Belief was known to be particularly prevalent. In the course of these investigations they learned more about the teachings of the beguny and were shocked to learn of their subversive ideas [Marsden, p. 83-117]. Some of the vast amount of material collected by the government expeditions was leaked to Alexander Herzen's "Fund of the Free Russian Press" in London. Herzen's band of radical socialist émigrés shared the government's view that Old Believer sects such as the beguny were potentially revolutionary, and they were eager to publicise evidence of this. Four volumes of material were published by Herzen's collaborator V. I. Kel'siev in 1860-1862, including a considerable amount of information about the beguny. Kel'siev's second volume contained the Compilation, a long and detailed treatise devoted specifically to demonstrating that Peter was the Antichrist [Собрание от Святого писания о Антихристе].

\section{The dating of the Compilation}

Kel'siev states that as well as A Compilation from Holy Scripture about the Antichrist, the anonymous treatise was entitled A Miscellany (Tsvetnik) and A Schismatic's Confession (Raskol'niche ispovedanie), but he did not provide a date or provenance for the text. In his Foreword to the volume, he claimed that the work dated back to the times of Peter the Great, but that the copy he had used was evidently distorted, and its numerous repetitions and general incoherence suggested that it combined various versions of the text [Кельсиев, с. XVII]. Kel'siev noted that some extracts from the work had already been published by A. P. Shchapov in his book on the schism, but that Shchapov's text differed somewhat from his [Там же]. Shchapov's "extracts" in fact resemble summaries of passages in the Kel'siev text: he described his source, in a footnote, as "a schismatic manuscript, headed, A petition or his- 
tory of Peter the Great. A Copy from the Solovetskii Monastery [Щапов, 1859, c. 109] ${ }^{1}$. Shchapov did not provide a date for the manuscript, but he cited it as evidence of the attitudes of Old Believers towards Peter in the first half of the eighteenth century, in spite of the fact that one of the passages he quoted included a reference to Kabinet Petra Velikogo ("The Cabinet of Peter the Great”), a work by O. P. Belyaev first published in 1793 [Там же, с. 109, 478].

In an essay on the beguny, however, which he published in 1862, Shchapov quoted much of the same material, citing its source as a pamphlet entitled, A Petition about the Antichrist who is Peter the Great, that circulated widely in towns and villages in the second half of the eighteenth century [Щапов, 1906, c. 567]. Shchapov described the petition as a general protest by the raskol [Там же], but he suggested that it was probably a begun composition, in view of its advocacy of flight (begstvo) as the path to salvation [Там же, c. 569]. Shchapov believed that the document expressed the main teaching of the beguny, as reflected in sources of authentic begun provenance; and he frequently cited it as a source for his account of the sect's ideology, in which criticism of Peter and his policies was very prominent [Там же, c. 567-575]2.

Where Shchapov had dated the Compilation to the second half of the eighteenth century, it was suggested elsewhere that it had been composed in the first quarter of the nineteenth century. In 1863, a version of the work was published in the prestigious journal of the Society for Russian History and Antiquities, under the title, A Copy of a Printed History about Peter the Great. In a footnote to the title, the anonymous editor noted, "There is no such printed history. This is an invention designed for concealment", and added that the work had been obtained from raskol'niki in Perm' province [Выписана История печатная о Петре Великом, с. 52] ${ }^{3}$. In a footnote to a later page which contained the date "1819", the editor asked: "Is this the year in which this fake history was written?” [Там же, с. 69] $]^{4}$.

In 1864, however, Fedor Eleonskii, a student at the St Petersburg Theological Academy, published his master's dissertation on The Condition of the Russian Schism under Peter I. Here, in a chapter on The Attitudes of the Fanatical Raskol'niki to Peter I, the author examined the Compilation, which he described as the "well-known raskolnik composition about the Antichrist who is Peter I" [Елеонский, с. 102]. Eleonskii admitted that in attributing this work to Peter's reign he was in disagreement with the accepted view that it dated from the late eighteenth or early nineteenth centuries. He recognised that the published versions of the text included what he described as various "supplements and insertions" from a later period, 490].

${ }^{1}$ For the extracts from the "petition", see: [Щапов, 1859, c. 106-109, 468, 478, 482-483,

${ }^{2}$ For his quotations from the document, see: [Щапов, 1906, c. 567-569, 570, 571, 573].

${ }^{3}$ The implication is that the Old Believers had given the manuscript this title in order to suggest that it had originated in a published work that had been approved by the censor.

${ }^{4}$ The Compilation mentions the year 1819 in the context of a complaint about Peter's calendar reform, arguing that 1819 should really be 1829 . The Old Believer calendar was usually eight (rather than ten) years ahead of the official calendar. 
but he argued that the work had originated in a shorter form in Peter's own day, when many of the apocalyptic ideas it expressed were current among the ordinary people [Елеонский, с. 102-103]. In his masterly study of the development of Peter's image throughout the eighteenth century, however, E. F. Shmurlo found Eleonskii's arguments unconvincing. Eleonskii had, for example, interpreted a passage in which the author expressed his refusal to obey "your emperor" as referring to Peter [Там же, с. 102], but Shmurlo pointed out that the wording in this and similar passages did not apply specifically to Peter as an individual, but rather to the Antichrist and whoever embodied him at the present time, whether that ruler be Peter or Alexander I [Шмурло, прим., с. 26-27]. Shmurlo concluded that the style and syntax of the Compilation indicated that it was not composed before the end of the eighteenth century [Там же].

One distinguished Western scholar, however, continued to follow Eleonskii in offering an earlier dating for the Compilation. The American historian Michael Cherniavsky cited it as evidence of Old Believer apocalyptic thought at the beginning of the eighteenth century, claiming that Eleonskii "shows convincingly that the work was originally composed immediately after 1725 , although most of the available manuscripts are of a later date" [Cherniavsky, p. 29, fn. 124]. Similarly, in her discussion of Old Belief under Peter, the British scholar Lindsey Hughes quoted an extensive passage from the document, describing it as "a contemporary tract" [Hughes, p. 356]. Neither Cherniavsky nor Hughes offered any explanation for the work's references to books published in the late eighteenth century, or its mention of the date 1819.

Russian historians in the Soviet period paid little attention to the Old Believers in general, and to the Compilation in particular. N. S. Gur'yanova based her work on Old Believer views of Peter as Antichrist on unpublished begun manuscripts dating from the late eighteenth and early nineteenth centuries. She did not directly utilise the Compilation, although her Appendices list a manuscript collection from the first quarter of the nineteenth century which contains an item entitled A Compilation from Holy Scripture about the Antichrist and the End Time which she describes as "part of" the work published by Kel’siev in 1861 [Гурьянова, с. 153, 179 № 111].

In his specialist study of the beguny, published in the post-Soviet period, A. I. Mal'tsev also did not directly use the Compilation; but he noted that some manuscript collections compiled in the second half of the nineteenth century include the work published by Kel'siev. In these collections, Mal'tsev tells us, the text of the Compilation, which - he says - was composed no later than the first third of the nineteenth century, is divided into two parts, and appears as two separate works, each of which is described as a "Christian manuscript from the time of the first revision". Mal'tsev observes, however, that the texts are sprinkled with references to books published in the 1780s and 1790s - indicating a later origin for the works. The backdating of such manuscripts, he suggests, represented a deliberately misleading attempt to demonstrate the antiquity (and hence the authority) of the texts [Мальцев, гл. V]. 


\section{Peter as Antichrist: the evidence from secular sources}

Although the Compilation contains many references to traditional sources of Old Believer apocalyptic thought, including the prophetic books of the Bible, the writings of the early Church fathers, and seventeenthcentury Muscovite publications of Ukrainian origin, such as the Book of St Cyril of Jerusalem and the Book of Faith, it also contains - as we have already noted - a number of quotations from secular works published in the late eighteenth century ${ }^{5}$. These sources provide a significant amount of "evidence" for the author's identification of Peter the Great and his successors as the Antichrist.

\section{Annunciation, Circumcision, Epiphany}

Much of the Compiler's "evidence" that Peter was the Antichrist comprises anecdotes about the tsar's biography, which draw parallels between Peter's life and that of Christ.

Peter, the author tells us, was conceived on his father's wedding night, 28/9 August 1671 - an event which was marked by the appearance of a comet, observed by the "magi (volkhvy)" Simeon Polotskii and Dmitrii Rostovskii'. These two men came to the palace on the morning of 29 August, "like the magi to Christ", and congratulated Tsar Aleksei on the conception of a son, who would be called Augustus (Avgust), after the month of his conception, and because he would rule like the Roman emperor Augustus Caesar; he would also be called Pakhomii (meaning "great") and Peter (meaning "rock" (cf. Matt.16:18)), and he would rule the "Scythian peoples" (249)7.

The author provides only a somewhat vague reference in support of this tale, to Anekdoty, t. 10 ("Anecdotes, vol. 10"). I have not been able to identify this source precisely, but the best-known of the various collections of "anecdotes" about Peter, which were a very popular genre in the late eighteenth century, is that compiled by Jacob von Stählin, who provides a version of the story reproduced in the Compilation ${ }^{8}$. According to Stählin [Штелин, c. 110-119 (анекдот № 118)], Simeon and Dmitrii gave the tsarevich the

${ }^{5}$ In addition to the works discussed below, the text includes two references [Собрание, c. 254, 263] to I. I. Golikov's Dopolnenie k Deyaniyam Petra Velikogo (Supplement to the Deeds of Peter the Great), published in Moscow in 18 vol. between 1790 and 1797.

${ }^{6}$ In fact, Aleksei married Natalia Kirillovna Naryshkina in January 1671, and Peter was born in May 1672 (which is consistent with his conception having taken place in August 1671). Simeon Polotskii (1629-1680) and Dmitrii Rostovskii (1651-1709) were both eminent Orthodox churchmen. Simeon lived in Moscow from 1664, but Dmitrii did not come to the Russian capital until 1701.

${ }^{7}$ Here and hereafter page references to the Compilation will be provided in round brackets. In the interests of stylistic variety, I shall sometimes refer to its anonymous author as "the Compiler".

${ }^{8}$ See: [Шмурло, с. 98; прим., с. 99-102] on the genre of anekdoty and bibliographical details of the many collections of anecdotes about Peter published in the late eighteenth century. Shmurlo defines anekdoty as tales about the facts of the ruler's personal life, many of which were legendary and expressed naïve enthusiasm for the tsar [Там же, с. 98; прим., с. 101]. 
name "Peter" and expressed the hope that he would civilise the "barbarous Scythians". Stählin does not mention the name "Pakhomii", but in another version of the story, Peter is given the name "Pakhom" or "Pakhomii" glossed as large, broad-shouldered and strong - by a mysterious holy man who also predicts that he will wield an imperial sceptre [Крекшин, 1787, c. 15-17]. Neither of these sources mentions the name Augustus, although avgusteishii ("most august") is a conventional Russian epithet for "emperor".

For the Compiler, of course, the tale of the magi who prophetically endowed Aleksei's son with a set of symbolic names was not just a harmless anecdote. According to traditional wisdom about the Antichrist, he was the mirror-image of Christ, and "proofs" that Peter was the Antichrist often included parallels between his biography and that of Christ [Елеонский, c. 102, 104-105; Cherniavsky, p. 30]. In this story about Peter's conception, we find a confused comparison not only with the Annunciation (when the Angel Gabriel visited the Virgin Mary to tell her that she would conceive a son whose name would be Jesus (Luke $1: 26-31$ )) but also with the Epiphany (when the magi, following a star, came to pay their respects to the Christ-child (Matt. 2:1-12)).

This tale about Peter's naming at the time of his conception is followed up later in the Compilation when the author denounces the tsar for changing the date of New Year from 1 September to 1 January. The September New Year, he recalls, had been introduced at the first ecumenical Church council, held at Nicaea under the Emperor Constantine in 325. All the holy Church fathers had bound their successors to observe it for ever more, so that Peter's breaking of this sacred vow made him accursed $(250,258,263,266)$. But even worse was the change to 1 January, which the Compiler frequently describes as the "Janus New Year" $(248,250,251,263,265,266,267)$ : a reference to Janus, the Roman god with two faces, one looking backward and the other forward, after whom the month was named. The Compiler's main objection to the January New Year is that Janus was a pagan deity, an ancient Roman idol to whom Peter allegedly established a temple and performed diabolical wonders (i. e. firework displays), at which all were encouraged to shout a triple "vivat?" in honour of the New Year (250, also 251).

Not only was it blasphemous for Peter to worship a Roman deity, in the Compiler's view, but the sacrilege was compounded by the fact that this pagan festival was held on a Christian holy day: 1 January was the Feast of the Circumcision, when the name of "Jesus", bestowed on the infant Christ by the angel Gabriel before his conception, was confirmed (Luke $2: 21$ ). This choice of date also involved a sinister parallel. "Jesus", we are told, means "saviour and lord of the world"; and on that very same day (i. e. 1 January) Peter was congratulated as "most august emperor", which means "ruler (obladatel') over all" (250-251-italics in the original; see also:

\footnotetext{
${ }^{9}$ Stählin's collection of anecdotes was first published in German in Leipzig in 1785; the first Russian translation appeared in St Petersburg in 1786: on the various editions, see [Шмурло, прим., с. 99-100].
} 
$253,255)$, thus, confirming the words of Hippolytus of Rome, that the Antichrist wanted to imitate the Son of God in every way (251).

At first sight this is all very confusing, since Peter changed the date of New Year in 1700, as our author knows (248), but did not adopt the title of emperor until 1721, as he also knows (253). It seems that he is deliberately conflating two events: the ceremony that marked the first January New Year in 1700 with a "diabolical" firework display; and the ceremony to celebrate the Treaty of Nystadt in October 1721, when the firework displays included a replica of the Temple of Janus in Ancient Rome, whose doors were closed as a sign of peace ${ }^{10}$.

It was at the Nystadt victory celebration that Peter was awarded the imperial title, so that by identifying the Nystadt triumph of 1721 with the introduction of the January New Year in 1700, the author is able to claim that, on the Feast of the Circumcision in 1700, Peter's designation as "the most august emperor" confirmed his naming as Augustus by Simeon Polotskii and Dmitrii Rostovskii on the day of his conception, just as the Angel Gabriel's naming of the Christ-child as Jesus at the Annunciation was confirmed at his circumcision on 1 January.

\section{Satan incarnate}

Later in his account, the author claims that Peter called himself "the divinity of Russia (bozhestvo Rossii: italics in the original)": as evidence, he quotes the lines:

Он бог твой, бог твой, о Россия!

Он члены взял в тебе плотские,

Сошед к тебе от горних мест $(256)^{11}$.

These words are taken from Lomonosov's Ode, but the Compiler references them to Kabinet Petra, a work which describes the contents of Peter's kunstkamera (Cabinet of Curiosities) in St Petersburg, where its author, Osip Belyaev, was the Superintendent. Belyaev, when describing the greatcoat Peter had worn at the Battle of Poltava, had wondered, “кто бы не ощутил достодолжного к Монарху сему благоговения, и не сказал бы в сердце своем: Он Бог, Он Бог твой был, Россия!.." 12 [Беляев, с. 94]. As Zhivov and Uspenskii noted, Lomonosov put these lines into the mouth of the god Mars, addressing the goddess Minerva; by equating Peter with a pagan rather than a Christian divinity, they suggested, the poet sought to avoid an ac-

\footnotetext{
${ }^{10}$ On the ceremony in St Petersburg, see, for example [Берхгольц, с. 201].

11 "He is thy god, thy god, O Russia! / In thee he assumed fleshly limbs, / Having descended to thee from the heights". Translation here and hereafter by M. P.

12 "Who would not feel fitting reverence towards this Monarch and say in his heart: 'He was God, he was thy God, O Russia!" Unlike the Compiler, Belyaev, who cites Lomonosov in a footnote, quotes the first line correctly. Belyaev had earlier used the term bozhestvo Rossii when he described an elderly visitor who referred to the wax figure of Peter in the kunstkamera as an image of the "divinity of Russia" [Беляев, с. 84].
} 
cusation of blasphemy [Живов, Успенский, с. 178]. In Belyaev's quotation, however, the line "Mighty Mars declares to Minerva" is omitted, so that the Compiler may be forgiven for assuming that Lomonosov was identifying Peter with the God of the Bible (256). Thus, the Compiler clearly interpreted the subsequent reference to the god's assumption of human flesh as a blasphemous reference to the incarnation of Christ, and, hence, as evidence that the tsar was none other than Satan - who, after he had been thrown out of the heavenly angelic ranks for his pride, "assumed fleshly limbs", as predicted by the Church fathers, and was incarnated in Peter (256-257).

Later, the author quotes (somewhat loosely, as Kel'siev observes in a footnote; and without providing a reference to either Lomonosov or Belyaev) an extract from another of Lomonosov's Odes (his ode on the anniversary of Elizabeth's accession to the throne in 1747), which was used as the epigraph to Belyaev's book: “зиждитель мира искони положил своими судьбами прославить в ваши дни, он послал в Россию человека, какой неслышим был от века..." (260) ${ }^{13}$. This quotation occurs in the context of another tirade by the author against Peter's pride, which he illustrates by reproducing (259-260) (again, without providing a reference) an extensive passage from P. N. Krekshin's Short Description of the Glorious and Memorable Deeds of the Emperor Peter the Great [Крекшин, 1788, c. 63-65] ${ }^{14}$. This is a curious work in which Krekshin (1684-1763) imagined conversations in the afterlife (the "kingdom of the dead") between Peter, on the one hand, and Ivan the Terrible, Charles XII of Sweden, King Solomon and Alexander the Great, on the other ${ }^{15}$. The passage quoted in the Compilation is taken from a speech which Krekshin put into Peter's mouth as a boast to Ivan the Terrible about his achievements, which the Compiler cites as an example of Peter's arrogance and his claim to God-like status (259). It is perhaps surprising that the Compiler should have allocated so much space to this enthusiastic apologia for Peter; his intention, it seems, was to present the tsar's achievements as the work of the Devil and to condemn him for boasting about them.

The Compiler appends to his version of Peter's speech some words which actually appear rather later in Krekshin's book, in an episode in which King Solomon provides his judgment of the relative merits of Peter and Charles XII [Крекшин, 1788, с. 95]: “...в величестве и в великославных делах Петру Великому от начала мира никто подобен не был"16 (260). The Compiler notes the similarity of this phrase to two apocalyptic Biblical passages, the first of which he paraphrases as: "зверь той горд

13 "In the beginning the creator of the world determined by predestination to glorify himself in your days. He sent to Russia a person who was unheard of from the beginning."

${ }^{14}$ The author has previously cited this work - as The Kingdom of the Dead (Царство мертвыс - as evidence for Peter's adoption of the title "Father of the fatherland" (omeu отечества) in 1721 (248).

${ }^{15}$ On this work, see: [Шмурло, прим., с. 62]. According to Shmurlo, such conversations among the dead were quite a common method of presenting historical events in the eighteenth century.

16 "In greatness and in glorious deeds no-one from the beginning of the world has been comparable to Peter the Great." 
и страшен, ни единому неподобный" (italics in the original) ${ }^{17}$ - a reference to the fourth Beast in the Book of Daniel (cf. Dan. $7: 7$ ); the second “кто подобен зверю и кто может ратоватися с ним?" 18 - refers to the Beast from the Sea in the Book of Revelation (cf. Rev. 13 : 4) (260). Since these apocalyptic Beasts are generally seen by Biblical scholars as analogous to Satan, the Compiler is here presenting Peter's alleged claim to be incomparable as further proof of his identity as the Antichrist.

\section{The spirit of Peter the Great}

The Compiler also cites Belyaev's Kabinet Petra when he makes the case that all Peter's successors on the throne are Antichrists. Belyaev had described how his visitor, standing in front of Peter's statue, exclaimed that Peter would always help the Russian army, because his spirit was alive in every Russian warrior, and “дух Великой Екатерины II есть дух Великого Петра, есть дух Самого Бога" 19 [Беляев, с. 85-86]. For the Compiler, of course, Peter's spirit was not that of God, but of Satan. "Зрите, человецы," he exclaims,

и вонмите, и разсмотрите по Святому Писанию, в киих летех жительствуем и кто ныне обладает вами! ибо дух Петров царствует во всех до скончания века, яко свидетелствует книжка К а 6 и н е т П е т р а; ибо дух государей российских есть дух Петра великого. Зрим, како дух его богоборной во всех властодержцах действует и действовати будет до скончания века... ${ }^{20}$ (254-255).

Later, the author declares that, "российские императоры от Петра и до окончания века - вси преемницы престола его и исполнители законов оного..." 21 (264).

On the basis of this idiosyncratic version of the argument that the current Russian ruler (presumably Alexander I) is the Antichrist, the author calls on all "true Christians" to reject any contact with the state: to refuse to register for the census, not to pay taxes, not to obey the laws, and not to accept the official calendar (251-267 passim). In these passionate appeals, the Compiler shows that he is a true disciple of Evfimii, and that he occupies a position close to that of the beguny, as Shchapov had pointed out in his essay on that sect (see above).

17 "That beast was proud and terrible, and not comparable to anyone."

18 "Who is comparable to the beast, and who can fight against it?"

19 "The spirit of the Great Catherine II is the spirit of the Great Peter, is the spirit of God himself."

20 "Look, O people, and hearken, and see in Holy Scripture, in what years we are living, and who now rules you! For the spirit of Peter reigns in them all until the end of time, as the little book Kabinet Petra bears witness; for the spirit of the Russian sovereigns is the spirit of Peter the Great. We see how his Godless spirit acts in all rulers, and will act until the end of time."

${ }_{21}$ "Russian emperors from Peter till the end of time are all the successors to his throne and executors of his laws." 
The evidence we have considered in this study suggests that the material in the Compilation that is derived from late eighteenth-century secular sources amounts to rather more than simply "supplements and insertions" to an earlier work, as Eleonskii described it (see above): rather, it provides an original and distinctive set of "proofs" of Peter's identity as the Antichrist; and strongly suggests that the work as a whole was written after the end of the eighteenth century, probably in 1819 , the year which the author mentions in relation to his critique of Peter's calendar reforms ${ }^{22}$. It suggests, too, that while Zhivov and Uspenskii were undoubtedly correct to observe that the metaphorical sacralisation of the ruler in secular works, such as the courtly panegyric odes of the mid-eighteenth century, contributed to Old Believer perceptions of the tsar as Antichrist, an important role was also played by more popular publications, such as the collections of anecdotes about Peter, which promoted a kind of "cult" of the tsar ${ }^{23}$. These latter works provided the general reader with an image of Peter as a God-like figure, which the Compiler was able to subvert in order to make the case for the tsar's Satanic identity.

\section{Список литературы}

Беляев О. П. Кабинет Петра Великого : в 3 ч. СПб. : Имп. акад. наук, 1793. Ч. 1. [6], $170 \mathrm{c}$.

Берхгольи Ф. В. фон. Дневник камер-юнкера Берхгольца : [в 4 ч.]. М. : Тип. Каткова и Ко, 1858. Ч. 1. 1721-й год. 275 с.

Выписана История печатная о Петре Великом. Собрание от Святого Писания о Антихристе // Чтения в Императорском обществе истории и древностей российских при Московском университете. 1863. Кн. 1. С. 52-71.

Гурьянова Н. С. Крестьянский антимонархический протест в старообрядческой эсхатологической литературе периода позднего феодализма. Новосибирск : Наука, 1988. $188 \mathrm{c}$.

Евфимий. Учение Евфимия (основателя Страннической секты в Ярославской губернии) // Сборник правительственных сведений о раскольниках, составленный В. Кельсиевым. Вып. 4. Лондон : Trübner \& Co, 1862а. С. 248-258.

Евфимий. Выписка из Цветника Евфимия // Сборник правительственных сведений о раскольниках, составленный В. Кельсиевым. Вып. 4. Лондон : Trübner \& Co, 1862b. C. 259-273.

Елеонский Ф. Г. О состоянии русского раскола при Петре I. СПб. : Тип. департамента уделов, $1864.158 \mathrm{c}$.

Живов В. М., Успенский Б. А. Царь и Бог : Семиотические аспекты сакрализации монарха в России // Успенский Б. А. Избр. тр. : в 3 т. М. : Гнозис, 1994. Т. 1. C. $110-218$.

${ }^{22}$ The $7^{\text {th }}$ revision (the first census to be conducted after the Napoleonic Wars), which was implemented between 1815 and 1825, is probably the census to which the author so frequently refers.

${ }^{23}$ N. S. Gur'yanova tells us that some begun authors of the late $18^{\text {th }}-$ early $19^{\text {th }}$ centuries made use of secular $18^{\text {th }}$-century publications in their writings about Peter as Antichrist [Гурьянова, с. 43-44]. 
Кельсиев В. И. Предисловие В. Кельсиева // Сборник правительственных сведений о раскольниках, составленный В. Кельсиевым. Вып. 2. Лондон : Trübner \& Co, 1861. C. III-XVIII.

Крекшин П. Н. Сказание о рождении, о воспитании и наречении на всероссийский царский престол его царского пресветлого величества государя Петра Первого. М. : Тип. Пономарева, 1787. [6], 58 с.

Крекшин П. Н. Краткое описание славных и достопамятных дел императора Петра Великого... Представленное разговорами в царстве мертвых... СПб. : Имп. тип., 1788. [4], 104 c.

Мальиев А. И. Староверы-странники в XVIII - первой половине XIX в. Новосибирск : Сиб. хронограф, 1996. $268 \mathrm{c.}$

Перри М. Русская народная эсхатология и легенда о Петре I - Антихристе // Вестн. С.-Петерб. ун-та. Сер.: История. 2016. Вып. 4. С. 77-86. DOI 10.21638/11701/ spbu02.2016.407.

Собрание от Святого Писания о Антихристе // Сборник правительственных сведений о раскольниках, составленный В. Кельсиевым. Вып. 2. Лондон : Trübner \& Co, 1861. C. $245-267$.

Шмурло Е. Ф. Петр Великий в оценке современников и потомства. Вып. 1 (XVIII век). СПб. : Сенат. тип., 1912. II, 108, 161 с.

Штелин Я. Подлинные анекдоты о Петре Великом : Собранные Яковом Штелиным : в 2 ч. 3-е изд. М. : Тип. Решетникова, 1830. Ч. 2. IV, 179 с.

Щапов А. П. Русский раскол старообрядства. Казань : Изд. книгопродавца Ивана Дубровина, 1859. [4], 547, [2] с.

Щапов А. П. Земство и раскол ІІ. Бегуны // Щапов А. П. Соч. : в 3 т. СПб. : Изд. М. В. Пирожкова, 1906. Т. 1. С. 505-579.

Cherniavsky M. The Old Believers and the New Religion // Slavic Rev. Vol. 25. 1966. № 1. P. 1-39.

Hughes L. Russia in the Age of Peter the Great. New Haven ; L. : Yale Univ. Press, 1998. $602 \mathrm{p}$.

Marsden T. The Crisis of Religious Toleration in Imperial Russia: Bibikov's System for the Old Believers. Oxford : Oxford Univ. Press, 2015. 304 p.

\section{References}

Belyaev, O. P. (1793). Kabinet Petra Velikogo v 3 ch. [The Cabinet of Peter the Great. 3 Parts]. St Petersburg, Imperatorskaya Akademiya nauk. Part 1. [6], $170 \mathrm{p}$.

Bergholz, F. W. von (1858). Dnevnik kamer-yunkera Berkhgol'tsa v 4 t. [The Diary of Kamer-Junker Bergholz. 4 Vols.]. Moscow, Tipografiya Katkova i Co. Part 1. 1721-i god. $275 \mathrm{p}$.

Cherniavsky, M. (1966). The Old Believers and the New Religion. In Slavic Rev. Vol. 25. No. 1, pp. 1-39.

Eleonskii, F. G. (1864). O sostoyanii russkogo raskola pri Petre I [On the Condition of the Russian Schism under Peter I]. St Petersburg, Tipografiya departamenta udelov. $158 \mathrm{p}$.

Evfimii (1862a). Uchenie Evfimiya (osnovatelya Strannicheskoi sekty v Yaroslavskoi gubernii) [The Teachings of Evfimii (the Founder of the Wanderer Sect in Yaroslavl Province)]. In Sbornik pravitel'stvennykh svedenii o raskol'nikakh, sostavlennyi V. Kel'sievym. Iss. 4. L., Trübner \& Co., pp. 248-258.

Evfimii (1862b). Vypiska iz Tsvetnika Evfimiya [An Extract from Evfimii's Miscellany]. In Sbornik pravitel'stvennykh svedenii o raskol'nikakh, sostavlennyi V. Kel'sievym. Iss. 4. L., Trübner \& Co., pp. 259-273.

Gur'yanova, N. S. (1988). Krest'yanskii antimonarkhicheskii protest v staroobryadcheskoi eskhatologicheskoi literature perioda pozdnego feodalizma [Peasant Anti-Monarchist Protest in Old Ritualist Eschatological Literature of the Late Feudal Period]. Novosibirsk, Nauka. 188 p. 
Hughes, L. (1998). Russia in the Age of Peter the Great. New Haven, L., Yale Univ. Press. 602 p.

Kel'siev, V. I. (1861). Predislovie V. Kel'sieva [Foreword by V. Kel'siev]. In Sbornik pravitel'stvennykh svedenii o raskol'nikakh, sostavlennyi V. Kel'sievym. Iss. 2. L., Trübner \& Co., pp. III-XVIII.

Krekshin, P. N. (1787). Skazanie o rozhdenii, o vospitanii i narechenii na vserossiiskii tsarskii prestol ego tsarskogo presvetlogo velichestva gosudarya Petra Pervogo [An Account of the Birth, Upbringing and Designation to the All-Russian Tsarist Throne of His Radiant Tsarist Majesty the Sovereign Peter I]. Moscow, Tipografiya Ponomareva. [6], 58 p.

Krekshin, P. N. (1788). Kratkoe opisanie slavnykh $i$ dostopamyatnykh del imperatora Petra Velikogo... Predstavlennoe razgovorami v tsarstve mertvykh... [A Short Description of the Glorious and Memorable Deeds of the Emperor Peter the Great... Represented in Conversations in the Kingdom of the Dead....]. St Petersburg, Imperatorskaya tipografiya. [4], $104 \mathrm{p}$.

Mal'tsev, A. I. (1996). Starovery-stranniki v XVIII - pervoi polovine XIX v. [The Old Believer "Wanderers" in the Eighteenth and First Half of the Nineteenth Centuries]. Novosibirsk, Sibirskii khronograf. 268 p.

Marsden, T. (2015). The Crisis of Religious Toleration in Imperial Russia: Bibikov's System for the Old Believers. Oxford, Oxford Univ. Press. 304 p.

Perrie, M. (2016). Russkaya narodnaya eskhatologiya i legenda o Petre I - Antikhriste [Russian Popular Eschatology and the Legend about Peter I as Antichrist]. In Vestnik SanktPeterburgskogo universiteta. Seriya: Istoriya. Iss. 4, pp. 77-86. DOI 10.21638/11701/ spbu02.2016.407.

Shchapov, A. P. (1859). Russkii raskol staroobryadstva [The Russian Schism of the Old Ritualists]. Kazan, Izdanie knigoprodavtsa Ivana Dubrovina. [4], 547, [2] p.

Shchapov, A. P. (1906). Zemstvo i raskol II. Beguny [Society and the Schism II. The Runaways]. In Shchapov, A. P. Sochineniya $v 3 t$. St Petersburg, Izdanie M. V. Pirozhkova. Vol. 1, pp. 505-579.

Shmurlo, E. F. (1912). Petr Velikii v otsenke sovremennikov i potomstva [Peter the Great in the Judgment of Contemporaries and of Posterity]. Iss. 1 (XVIII vek). St Petersburg, Senatskaya tipografiya. II, 108, $161 \mathrm{p}$.

Sobranie ot Svyatogo Pisaniya o Antikhriste [A Compilation from Holy Scripture about the Antichrist]. (1861). In Sbornik pravitel'stvennykh svedenii o raskol'nikakh, sostavlennyi V. Kel'sievym. Iss. 2. L., Trübner \& Co., pp. 245-267.

Stählin, J. von (1830). Podlinnye anekdoty o Petre Velikom. Sobrannye Yakovom Shtelinym $v 2$ ch. [Authentic Anecdotes about Peter the Great. Collected by Jacob von Stählin. 2 Parts]. $3^{\text {rd }}$ Ed. Moscow, Tipografiya Reshetnikova. Part 2. IV, 179 p.

Vypisana Istoriya pechatnaya o Petre Velikom. Sobranie ot Svyatogo Pisaniya o Antikhriste [A Copy of a Printed History about Peter the Great. A Compilation from Holy Scripture about the Antichrist]. (1863). In Chteniya v Imperatorskom obshchestve istorii i drevnostei rossiiskikh pri Moskovskom universitete. Book 1, pp. 52-71.

Zhivov, V. M., Uspenskii, B. A. (1994). Tsar' i Bog. Semioticheskie aspekty sakralizatsii monarkha v Rossii [Tsar and God. Semiotic Aspects of the Sacralisation of the Monarchy in Russia]. In Uspenskii, B. A. Izbrannye trudy v 3 t. Moscow, Gnozis. Vol. 1, pp. 110-218. 